\title{
CESIS
}

Electronic Working Paper Series

Paper No. 01

\section{A Comparative Perspective on Innovation and Productivity in Manufacturing and Services ${ }^{1}$}

\author{
Hans Lööf
}

(INFRA, SISTER)

January 2004

The Royal Institute of technology Centre of Excellence for studies in Science and Innovation www.infra.kth.se/cesis/research/workpap.htm Corresponding author: hansl@infra.kth.se

\footnotetext{
${ }^{1}$ Status of the paper: The paper reviewed and revised for publication in the 2002 Gainesville International Schumpeter Society proceedings.
} 


\title{
A Comparative Perspective on Innovation and Productivity in Manufacturing and Services
}

\author{
HANS LÖÖF*, \\ Royal Institute of Technology \\ Centre of Excellence for Science and Innovation Studies
}

First version August 2002, Revised January 2004

\begin{abstract}
This paper serves as another complementary link in a chain of a rather limited number of investigations in the R\&D-innovation-productivity relationship within service industries. Innovation has been found to be a major contributor to productivity growth in manufacturing. In this paper, the importance of innovation is explored by comparing manufacturing and service firms in a sample of knowledge intensive industries. In particular we intend to find evidence on the following two issues. First, is there any evidence that the reported weak rate of productivity growth in knowledge intensive services can be explained by a low propensity to be innovative? Second, is it possible that knowledge intensive service firms are less efficient in deriving benefits from innovation than knowledge intensive manufacturing firms? Empirical results based on innovation survey data indicate a surprising similarity in innovation performance between the two categories of firms.
\end{abstract}

Keywords: Productivity, Innovation, Manufacturing, Services, Applied Econometrics JEL Classification Numbers: C31, D24, L60, L80 O31

\footnotetext{
* Correspondence to Hans Lööf, Royal Institute of Technology, Centre of Excellence for Science and Innovation Studies, SE-10044 Stockholm, E-mail: hansl@infra.kth.se. Phone +46-8-790 8012.

The author gratefully acknowledges financial support from Vinnova, Swedish Agency for Innovation Systems. The author would like to thank Almas Heshmati, Gunnar Eliasson, Roger Svensson and one anonymous referee for very helpful comments and suggestions on an earlier version of this paper.
} 


\section{INTRODUCTION}

The purpose of this paper is to bring a comparative perspective into the relationship between innovation and productivity in manufacturing and services. A large number of studies have been done on the innovation - productivity link in the manufacturing sector. This study reports new results on this link by incorporating services into the analysis.

The uniqueness of this paper is that it is one of the first attempts to estimate a quite large number of firm level observations from both manufacturing and service firms based on an identical questionnaire as well as an identical modeling framework.

During the last two decades the rate of growth in the manufacturing sector in Sweden has been about twice as high as the growth rate in the service sector. Finding a similar pattern in the U.S. economy, Triplett and Bosworth (1999) refer to the classical Baumol (1967) article and argue that if the data is right, one might infer that the shift in the economy towards a larger share of services, implies slower growth in the aggregate productivity of the total economy. $^{2}$

This paper considers two different samples of knowledge intensive firms, which represent some of the most dynamic parts of the Swedish economy when value added is considered. First we have a bunch of manufacturing industries: pharmaceuticals; machinery and equipment; office machinery and computers; electrical and communication equipment; instruments and watches; and transport equipment. They are defined as knowledge-intensive according to their high degree of R\&D intensity. The second category is business service firms whose knowledge intensity is reflected in the high ratio of employees with a university degree to the total number of employees as well as in a high ratio of $R \& D$ investments to sales.

Since the beginning of the 1980s, the average annual growth rate in value added has been an impressive 5 percent for both knowledge intensive manufacturing and business services. The reported growth rate in labor productivity, however, differs considerably. While the average value added per working hour in knowledge-intensive manufacturing increased by 130 percent between 1980 and 1998, the corresponding rate of growth in business services was only 20 percent or about one percent per year.

\footnotetext{
2 There is also a large degree of heterogeneity in the annual productivity growth rates in the manufacturing sector. The extremes of the 2-digit ISIC code levels in Sweden are on the one the end electrical and communication equipment, with more than $10 \%$ annual growth rates, and on the other office machinery computers, with a negative rate of growth. The service sector shows smaller disparities between individual industry growth rates, but there are rather substantial differences. For example between post and telecommunications on the one hand, and personal services and hotels and restaurants on the other.
} 
One possible explanation for this large difference in growth rates is that it is much harder to increase productivity in service producing industries than in manufacturing, in line with the Baumol hypothesis. But the figures might also be incorrect. It is well documented in the literature that there are notorious problems measuring service production. ${ }^{3}$

In this paper two in several aspects homogenous samples of manufacturing and service firms are compared. Both have domestic manufacturing firms as the main customers, and knowledge is a crucial production factor for competitiveness and survival. An important difference, however, is that while manufacturing firms operates on the global market, service firms produce for the national market.

Two issues related to the differences in productivity growth are explored in some detail. First, since innovations have been found to be a major contributor to productivity growth in manufacturing, is there any evidence that the average business service firm has a lower propensity than the average knowledge intensive manufacturing firm to be innovative? Second, is it possible that the business service firms are less efficient in deriving benefits from innovation?

The empirical part is based on matched firm-level data collected from Statistics Sweden and observations from an innovation survey, conducted in 1999, based mainly on the Community Innovation Survey (CIS)-methodology. ${ }^{4}$ The survey was among the first to utilize the internationally harmonized CIS questionnaire in order to receive information about both innovation input and innovation output from manufacturing firms as well as from service firms. Moreover, in addition to the ordinary CIS questions on cooperation, information, strategy and obstacles when innovation are considered, this particular survey is also enlarged with information on product life cycles, growth rate on the markets, factors important for competitiveness of the products and categories of customers.

A central issue in the analysis is the choice of the methodological approach. A simultaneous system of equations is here estimated, based on a production function approach where it the relationship between innovation input, innovation output and productivity is modeled and estimated jointly.

The remainder of this paper is organized as follows: Section 2 briefly discusses some problems concerning measurement of productivity. Section 3 describes the specific features of

\footnotetext{
${ }^{3}$ For instance, see Fuchs (1969) Mohr (1992), Griliches (1992), Griliches and Mairesse (1993), Sherwood (1994), Armknecht, Lane and Ginsburg (1992), Dean and Kunze (1992), Armknecht, W. F Lane, and Stewart (1997) Baily and Zitzewitz (2001), Heshmati (2003).

${ }^{4}$ For more information about the Community Innovation Survey see OECD 1997.
} 
the data set. The empirical model is provided in Section 4. The estimation results are given in Section 5. Section 6 summarizes the main findings.

\section{MEASURING OF PRODUCTIVITY}

In the two-sector growth model of Baumol (1967), the production functions in manufacturing and services are represented by a technologically advanced manufacturing sector and by a stagnant service sector. The model predicts that the stagnant service sector will, over time, absorb more and more workers to satisfy growth in demand because there are fewer opportunities to substitute technological advancements in machinery and equipment for labor.

The slow growth reported in services such as hotels and restaurants, large parts of the health care industry, transportation, education, and various parts of the public sector, is probably measured correctly. It might reflect slow technological change resulting from the labor-intensive nature of such industries and a high income elasticity for the demand for such services is in line with Baumol's predictions.

However, the concept of service covers a heterogeneous set of industries, and recent years have seen a sharp growth in investment in new technology in finance, post and telecommunications, business services and wholesale and retails. Given the fact that business services are an industry where output is measured with difficulties, it is likely that the reported weak productivity growth partly is a result of the notorious problems in measuring quantitative as well as qualitative output in service production. ${ }^{5}$

Quantitative estimates of the growth in real output have a general and pervasive Achilles' heel not only in service industries. To measure the real output one need to know their total revenue and have access to adequate information in order to construct an appropriate price index for it. Similarly, in order to measure inputs in real values, one needs information on inputs used in production (total costs and prices or units used). In both cases we have to deal with the problems of quality changes and the continuous emergence of new products and services, and the disappearance of old ones. ${ }^{6}$ This is a problem facing large parts of the

\footnotetext{
${ }^{5}$ The integration of computers in the economy has aggravated this problem. According to Triplett and Bosworth, the industries that are the largest purchasers of computers in the U.S. are all service industries and, ranked by intensity of usage, financial services, wholesale trade, business services, insurance and communications. In these industries, computers have created new forms of service production that hardly is reflected in the statistics.

${ }^{6}$ A presence of a quality-based index, however, is by no means a guarantee of good quality in the measurement process. Nordhaus (1997) argues that the standard methodology of price indices has only captured a small amount of the revolutionary improvements in economic life from the massive changes in transportation, communications, lighting, heating and cooling and entertainment
} 
modern knowledge intensive production, regardless of whether they are manufacturing or services. However, these kinds of difficulties are reduced to a minimum since we only look at cross-sectional data.

\section{DATA AND VARIABLES}

The first two rounds of the Community Innovation Survey, launched by Eurostat and national agencies within the EU and some other countries during the 1990s, provided quantitative firm-level data on both innovation input and innovation output. However, the innovation output data is limited to manufacturing industries and there is a strong focus on technological innovations, which hampers a comparative analysis of the economic impact of innovations in both manufacturing and service industries.

In order to compare both categories of firms, Statistics Sweden launched a modified questionnaire of the CIS style in the 1999. The questionnaire was then sent out to both manufacturing and service firms. The questions are identical, which gives the opportunity to analyze differences and similarities in the link between innovation and productivity for the two industries. The survey data is further matched with register data adding economic variables for each of the observed firms.

The sample used in this study is drawn from a stratified random sample and consists of 607 knowledge intensive manufacturing firms and 538 business service firms. To get as homogenous comparison samples as possible, censoring has eliminated the influence from extreme outliers. ${ }^{7}$ Moreover, weighted factors are used for estimation meaning that differences in the number of firms in a given strata and the number of respondents in the survey is taken into account so that the observations represent the whole population of firms in a given size and class of firms.

Tables 1-3 give some details of the sample used. It considers an overall sample of 1,145 observations with 20 or more employees and a subsample of 526 innovative firms. In this paper a firm is defined as innovative if it has both expenditures on innovation activities as well as positive revenues from innovations launched on the market during the last three years. $^{8}$

\footnotetext{
${ }^{7}$ Methods for censoring and treatment of missing variables are provided in Appendix A.

${ }^{8}$ It could be questioned whether the three-year period is too short to measure the economic results of innovations, or not. Recent empirical research, however, supports the view of an ongoing process of shorter product life cycles, reduced time to market for new product development and an increasing share of sales deriving from new products. Choperena (1996) finds that many firms see cycle time acceleration as a way to increase their market competitiveness. Studying the time it takes from the basic idea to commercialization for 610 innovations in the Finnish economy, Palmberg et al (2000) find that close to 50\% of all innovations
} 
Table 1 report mean and standard deviation for some key variables of interest collected from firms' annual reports, educational statistics and the survey. Starting from Panel A, the overall samples shows that the average manufacturing firm is larger than the average service firm, 218 and 99 employees respectively. The frequency of temporary hired employees is rather similar. The intensity of both human capital and R\&D investment is highest among business services while the average knowledge intensive manufacturing firm proportionally invest more in physical capital (gross investment) and also has higher sales income per employee.

Innovation output measured as the ratio of innovation sales to total sales is about the same size for both sub-samples. Finally, innovation sales per employee is higher for the manufacturing sample while the average business firm has higher level value added per employee (labor productivity).

The main difference between the overall samples in Panel A and the innovative samples in Panel B is that innovative firms have higher levels of sales, labor productivity and human capital.

The firm characteristics presented in Table 2 reveals some interesting similarities between the two samples. Surprisingly, about half or more of the firms report that the average life cycle (length of life) of the average product is 7 years or more. About two out of five firms in both groups consider quality to be of critical importance for competitiveness of their products. A majority of the firms in both knowledge-intensive manufacturing and business services carry out some kind of product innovation. Manufacturing firms are the main customers for both groups.

According to the definition used in this paper, 53 percent of the manufacturing and 40 percent of the service firms are innovative. In agreement with previous findings i.e. Cohen and Levinthal (1990), Freeman (1991), Murray et. (1996), Pyka (2000), a majority of both categories of innovative firms carry out innovation in cooperation with other partners like universities, research institutes, customers, suppliers, consultancies, competitors and others. Moreover, about $50 \%$ of the innovative firms purchase professional services to support their

developed from the basic idea into commercialization in less than 2 years in both manufacturing and in services. The time from commercialization of the innovations to break even was also found to be surprisingly similar between services and manufacturing, within 2 years for about $70 \%$ of the innovations in both sectors. These findings are in sharp contrast to the results from similar studies carried out four decades ago. For example, Jewkes, Sawers and Stillerman (1958) identified fifty-one inventions and found that the mean lag between invention (the idea) and innovation (introduction of the idea to the market) was 12.5 years and the lag exceeded 20 years for 30 percent of these inventions. About two decades later Ravenscraft and Scheerer (1982) report a reduced lag structure of only 4-5 years from innovation input to innovation output. 
internal innovative activities. A majority of firms innovating products are also focusing on organizational innovations and process innovations as well, indicating close relationship between these forms of innovations.

The results presented in Table 3 indicates a large degree of similarities between the manufacturing firms and business firms when factors such as cooperation on innovation, strategy on innovation, sources of information for innovation and obstacles to innovation are considered. The only main difference is that the innovation partner of knowledge-intensive firms often is at the global arena while business firms cooperate with regional or national partners of innovation.

\section{THE ANALYTICAL FRAMEWORK}

\subsection{Formulation of the model}

There are several difficulties in trying to establish the causal relationship between innovation input and innovation output, and also between innovation output and productivity in this study. One difficulty is simultaneity; most of the variables of interest in this study tend to change simultaneously, and it is not easy to untangle their separate effects. Another difficulty is sample selection. Sample selection arises when the observed sample is not randomly drawn from the population of interest. Failure to take simultaneity and sample selection into account can potentially lead to inconsistent and biased estimates of the parameters of interest. In order to handle both these problems, this study relies on a simultaneity equation model as well as on a generalized tobit model. The main idea behind this type of modeling is described by Crépon, Duguet and Mairesse (1998) and by Goux and Maurin (1998). Lööf and Heshmati (2002, 2004) describe the particular specification of the model used. We will briefly recapitulate some of the main features of the model here.

The theoretical framework for the model is a Cobb-Douglas production function with the main variables expressed as:

$$
Q=A X^{\alpha} K^{\beta} e^{\lambda t+u}
$$

where $Q$ is the rate of productivity, $A$ is a constant, $X$ is a vector of conventional input variables such as labor, capital and so forth, $K$ is a measure of technical knowledge, and $u$ stands for all other unobserved determinants of productivity. $\alpha, \beta$ and $\lambda$ are parameters that we are interested in estimating. 
The empirical model is a structural model consisting of four equations and estimated in a multi-step procedure. In the first step, firms decide whether or not to engage in innovation activities (selection equation), and on the amount of money to invest in innovation. This is specified by a generalized Tobit model. Given the fact that the firm has decided to invest in innovative activities, the second step links the actual level of investment to its determinants. In the third and fourth steps, the generalized Cobb Douglas production function describes the effect of innovation investment on innovation output, and innovation output on productivity in a simultaneous system. More specifically, the model is given by the following four equations:

$$
\begin{gathered}
y_{0 i}=\left\{\begin{array}{lll}
1 & \text { if } \quad y_{0 i}^{*}=X_{0 i} \beta_{0}+\varepsilon_{0 i}>0 \\
0 & \text { if } \quad y_{0 i}^{*}=X_{0 i} \beta_{0}+\varepsilon_{0 i} \leq 0
\end{array}\right. \\
y_{1 i}=y_{1 i}^{*}=X_{1 i} \beta_{1}+\varepsilon_{1 i} \text { if } y_{0 i}=1 \\
y_{2 i}=\alpha_{21} y_{1 i}+\alpha_{23} y_{3 i}+X_{2 i} \beta_{2}+\varepsilon_{2 i} \text { if } y_{0 i}=1 \\
y_{3 i}=\alpha_{32} y_{2 i}+X_{3 i} \beta_{3}+\varepsilon_{3 i} \text { if } y_{0 i}=1
\end{gathered}
$$

where $y_{0 i}^{*}$ is a latent innovation decision variable measuring the propensity to innovate, $y_{0 i}$ is the corresponding observed binary variable being 1 for innovative firms. $y_{1 i}, y_{2 i}$ and $y_{3 i}$ describe innovation input, innovation output and productivity. $X_{0 i}, X_{1 i}, X_{2 i}$ and $X_{3 i}$ are vectors of various variables explaining innovation decision, innovation input, innovation output and productivity. The $\beta$ 's and $\alpha$ 's are the unknown parameter vectors. $\varepsilon_{0 i}, \varepsilon_{1 i}, \varepsilon_{2 i}$ and $\varepsilon_{3 i}$ are i.i.d. drawings from a multivariate normal distribution with zero mean, with the exception of two cases (equation (2) and (3), and equation (4) and (5)) not correlated.

For estimation purposes we apply a two step estimation procedure. In the first step the generalized Tobit model, comprising the selection equation (2) and the innovation input equation (3), is consistently estimated by full maximum likelihood techniques, using observations on both innovative and non-innovative firms. The estimates of this first step are used to construct an estimate for the inverse Mills' ratio, which is incorporated as an explanatory variable in the estimation of both structural equations (4) and (5) to correct for potential selection bias. To take into account the possible problem that explanatory variables are determined jointly with the dependent variable, i.e. they are not exogenously given, which highlights the simultaneity problem, the last two equations are estimated in a simultaneous equation system relying on the instrumental variable approach (2SLS and 3SLS respectively). 
For the estimation of this part of the model only, observations from the innovative firms are used.

\subsection{Specification of the model}

The specification of the model starts with the selection equation (2). As reported in the surveys by Cohen and Klepper (1996) and by Klette and Kortum (2002) size has been found to be a highly significant determinant of engagement in innovation activities. In addition to size, gross investment per capita is included. The selection equation also controls for products life cycle, factors very important for the competitiveness of the firm's products, and if the main customer is located abroad.

The size of innovation investment expenditure per employee (equation (3)) is explained by firm size, temporary employment and by a number of indicator variables: obstacles to innovation; localization of innovation partners; critical sources of information for innovation; factors very important for the competitiveness of the firm's products.

In the innovation output (equation (4)), the most important explanatory variable is innovation input. The other continuous variables are capital intensity (proxied by gross investments per employee), labor productivity and firm size. The discrete explanatory variables (indicator variables) are innovation strategy, information sources, cooperation partners, localization of innovation partners, product life cycle, and growth rate on the firm's main market.

The final relationship is the productivity equation (5). Traditionally, the literature uses R\&D as an independent variable. But thanks to an important novelty in the CIS style of data, we can use innovation output instead. In addition, we are following the literature and control for variations in firm size, physical capital and human capital. Moreover, the productivity equation controls for process innovations and organizational innovations.

It is to be noted that in all equations the intensity variables are expressed in logarithmic terms and each of the four equations includes industry dummy variables.

\section{THE EMPIRICAL RESULTS}

The main hypothesis to be investigating in this study was whether there is any evidence for the notion that service industries have a lower propensity to be innovative or whether they are less efficient in deriving benefits from innovations. The correlation analysis presented in Table 4 indicates a close correlation between $R \& D$ investments and innovation output as well as between innovation output and productivity for both samples of firms. 


\subsection{Investigation of robustness of the model}

In Table 5, regression results are presented which summarize, for a sample consisting both of knowledge intensive manufacturing firms and business service firms, the relationship between the probability of investment in R\&D and labor productivity. Note that the full model contains all variables described in the model specification, only a few selected variables will be discussed here in order to conserve space.

Each of the four regressions includes industry dummy variables, allowing for separate industry intercepts. On the whole, the results are very encouraging. The estimated coefficients of firm size, R\&D, innovation output, labor productivity and human capital and physical capital (all in logs) are principally reasonable and highly significant. In equation (4), gross investment is used as a proxy for physical capital (stock) and the coefficient should be of an order of 0.1-0.2. However, the order of magnitude (0.03) is not quite what we expected and it indicates that it is problematic to use a flow measure as a proxy for stock when physical capital is considered. The elasticity of innovation input with respect to $R \& D$ is quite large (0.4). In this case, using a flow of $R \& D$ investments as a measure of the $R \& D$ stock may overestimate the latter for large companies with a long R\&D history (Griliches 1998). Perhaps this is why the estimate is somewhat biased upwards.

The coefficients of innovation output $(0,16)$ and human capital $(0.5-0.7)$ in equation (4) are close to what has been reported in previous studies using a similar model (Crépon et al 1998, Lööf and Heshmati 2004).

Modern innovation literature (se for example Cohen and Klepper, 1996) finds that the probability of being engaged in innovation increases with firm size, but the R\&D intensity is not higher for large firms than for small firms. The present model capture the latter fact and in congruence with Janz et al (2004), the sign is negative meaning that smaller knowledge intensive firms invest proportionally more in R\&D per capita than larger knowledge intensive firms. The non significant size estimate in the probit equation can partly be explained by the fact that service firms are included in the sample.

Finally the inverse mills' ratio indicates the presence of selectivity problem in step two of the model, and the method used to account for such effect by the selectivity equation is more efficient. The Likelihood-ratio test (LR) indicates a necessary independence of the selection and input equation in the first of the two steps of the model. 


\subsection{Determinants of $R \& D$}

In Tables 6 and 7 the relationship between $R \& D^{9}$ and its determinants is examined separately for both categories of firms. Starting with Table 6 and the selection equation, it is shown that the probability of doing R\&D increases with size only for manufacturing firms (weakly significant). Another difference is that R\&D engagement increases with the size of gross investment but only for manufacturing firms. However, the inclusion of physical capital as an explanatory variable is a problem in this equation, since it might include $R \& D$ embedded machinery and equipment and the exogeneity may therefore be questioned. Since a removal of this variable don't have any significant impact on equation (1), nor on the other regressions it is used for of comparability reasons. A third and not unexpected difference is that the likelihood of R\&D-investment is significantly correlated with the main customer located abroad for the average manufacturing firm but not for the average business service firm. Using product life cycle indicate a negative impact on $R \& D$ engagement for manufacturing and service firms. However, it is significant only for the former category of firms.

It should be noted that there are inconsistencies in the results obtained when the estimates for knowledge intensive manufacturing firms and business service firms are considered.

Table 7 provides more details on R\&D determinants, showing the results of the elasticity of $\log R \& D$ per employee. The coefficient for firm size is negative and highly significant for both industries. When looking at the log of temporary employment a significant estimate is revealed (at the $5 \%$ level) in the order of a magnitude of 0.17 for manufacturing firms. Outsourcing is usually defined as the replacement of internally provided activities in the production process for externally produced goods and services. Concentration on core business, core technologies and specialized competence are commonly referred to as main causes of outsourcing. The hiring of workers in non-traditional jobs can also be defined as a kind of outsourcing. ${ }^{10}$ Assuming that this variable can be interpreted as a proxy for total

\footnotetext{
${ }^{9}$ In the CIS questionnaire, innovation input includes R\&D and some other expenditures on innovation such as training related to $R \& D$ activities and market introduction of new goods. However, R\&D is the vast major part of innovation expenditures.

${ }^{10}$ Falk and Koebel (2000) include temporary personnel services their definition of outsourcing, and using the same definition Estevão and Lach (1999) identify several distinguished reasons for hiring "temporary workers". Primarily, this is one important aspect of the general trend toward flexible and specialized work arrangements by firms. They find that this kind of outsourcing is motivated by: (1) the potential for implementing a two-tier wage structure by contracting with firms that pay lower wages; (2) the possible realization of scale economies as a result of specialization in the provision of specific tasks; (3) the potentially higher productivity of specialized temporary workers, in relation to what could have been gained if the firm had to learn and build up related knowledge internally; (4) and the ability to adjust the level of employment rapidly in response to temporary and/or uncertain changes in demand
} 
outsourcing, the regression results in both equation (1) and equation (2) indicate that outsourcing strategy has a positive impact on $R \& D$ in the average knowledge intensive manufacturing firm. This confirms previous finds by for example Ulset (1996) and Deavers (1997). This variable is not significant for the service sample.

The dummy variable for global innovation partner is highly significant for both samples. Among manufacturing firms, the R\&D intensity increases with “market” (customer, suppliers and competitors) as a crucial source of information for innovation.

Somewhat unexpected, the indicator variable for "quality" as a very important factor for the competitiveness of the product is negative and highly significant for manufacturing as well as for services. A tentative interpretation is that this variable captures marginal improvements rather than radical innovations.

\subsection{Innovation and productivity}

Table 7 and 8 present 2SLS and 3SLS estimates of the simultaneous equations for both samples. The coefficient estimates for the two alternative estimation methods are rather close. Of more interest, the results for the key variables are roughly similar for manufacturing and services. The elasticity of labor productivity with respect to innovation output, and the elasticity of innovation output with respect to innovation input, is somewhat lower for manufacturing firms. But the differences are not statistically significant.

The estimates for the innovation output regression are presented in Table 7. When looking at the main variables, it shows nearly identical R\&D elasticities in the 3SLS regressions, 0.45 versus 0.43 . However, the slightly higher coefficient for manufacturing is somewhat more efficient and significant at the $1 \%$ level, while the service estimate is significant at the $5 \%$ level of significance. The coefficients indicate that a 10 percent increase in innovation expenditures per employee at the margin raises innovation sales per employee by 4 percent. When using the 2SLS, it results in coefficient estimates of 0.50 for the average manufacturing firm and 0.57 for the average service firms. The latter is only weakly significant.

The model allows for feedback effects of productivity on innovation output. The order of magnitude of the resulting estimate is about 1.0, but significant only in the manufacturing sample. Gross investment, the proxy for physical capital, correlates negatively with innovation output for manufacturing firms and is neutral when service firms are considered. There is no indication of a significant increased or decreased research productivity to firm size for knowledge intensive firms. The Mills' ratio, correcting for possible selection bias, is highly significant and the size of the coefficient is lager in the service sample. 
The indicator variables are mostly insignificant in the service sample with the exception for innovation output, which increases with replacement of products phased out as an important cause to R\&D-investments, and decreases with the firm or the group as a very important source of information for innovation. The regression results for the manufacturing sample shows that the R\&D productivity increases with short product life cycles and national innovation partners. On the contrary, the sign is negative for (i) bad growth rate on the main markets, (ii) global innovation partners, (iii) the own group or (iv) a bunch consisting of consultancies, universities, inventors and non-profit research institutes as a very important cooperation partner for innovation, (v) the market as a very important source of information, and (vi) extending the product range as innovation strategy. Due to limited spaces a detailed analysis of these estimates is not possible. The conclusion is that despite differences among the coefficients for various indicator variables, there is a striking similarity between knowledge intensive manufacturing and service firms when the link between $R \& D$ and innovation output is considered.

The relationship between productivity and its determinants is investigated for the two samples in Table 9. The elasticity of log labor productivity with respect to log innovation output per employee is surprisingly similar for both categories of firms. The order of magnitude is about 0.11 among manufacturing firms and about 0.14 among service firms in the 3SLS regressions. Both estimates are highly significant. Using 2SLS for checking the robustness of the results, it only resulted in minor changes in estimates, 0.12 versus 0.15 . In both samples labor productivity increases quite extensively with human capital but not with firm size. The sign for gross investment as a proxy for physical capital is expected, but the coefficient estimate is low and non significant for the average manufacturing industry.

To conclude, we find only minor differences between knowledge intensive manufacturing and knowledge intensive services when the importance of innovation is considered. However, two major issues are comparability of innovation output between manufacturing and services, and the lag structure within both industries. In the model used, an underlying assumption is than an innovation is an innovation, irrespectively if it is created in a service firm or in a manufacturing firm. Concerning lags, the main drawback with the R\&D variable used, is that it is a flow variable and observed only in the same year as we observe innovation output. This means that the lag between investment in research and the actual product innovation is ignored, and so is the lag between product innovation and introduction to the market. The underlying assumption here is that firms’ R\&D behavior are constant over time. 


\section{CONCLUSIONS}

This paper can be viewed as another complementary component in the chain of a rather limited number of investigations on the $R \& D$-innovation-productivity relationship within service industries. Two main research issues were addressed here. First, since innovations have been found to be a major contributor to productivity growth in manufacturing, we ask is there any evidence that the average service firm has a lower propensity than the average manufacturing firm to be innovative? Second, is it possible that the service firms are less efficient than manufacturing firms in deriving benefits from innovation?

The data set used for the analysis is taken from the largest innovation survey $\mathrm{t}$ ever conducted in Sweden. The questionnaire launched by Statistics Sweden was answered by 50 percent of all manufacturing and service firms that existed in Sweden in 1998 and 20 or more employees. From this overall sample this study is based on subsample of 1,145 knowledge intensive manufacturing and service firms. The motivation for this selection was an assumption of rather homogenous and comparable firms. This was also confirmed by the descriptive statistics.

In spite of various limitations and difficulties faced, this paper finds a rather consistent positive relationship between $R \& D$, innovation and productivity for both knowledge intensive manufacturing firms and business service firms. The R\&D investments as a share of sales or per employee are higher in the average service firms, it is true, but using a Cobb-Douglas type production function the estimates indicate an elasticity of innovation output with respect to innovation input of about 0.4 for both samples of firms. Considering the link between innovation and labor productivity, the regression results show highly significant estimates in the order of magnitude of about $0.10-0.15$ for both industries. The manufacturing estimate is consistent with previous results in the literature, while there are few studies so far that have presented quantitative productivity analysis in the service sector based on rather large microeconomic datasets on innovation activities.

Given that the estimation results, the validity of the data, and the model used are not questioned, and assuming that the sample used are representative for the populations studied, will suggest that $R \& D$ and innovation contributes very little to the reported large differences in productivity growth between knowledge intensive manufacturing firms and knowledge intensive service firms. 


\section{REFERENCES}

Armknecht, P.A., W. F Lane, and D.H. Ginsbsurg (1992), “Improvements in Measuring Price Changes in Consumer Services: Past Present and Future”, In Z. Griliches (ed.) Output Measurement in the service sector, Studies in Income and Wealth. NBER and University of Chicago Press, 109-156.

Armknecht, P.A., W. F Lane, and K.J. Stewart (1997), "New products and the U.S. Consumer Price Index”, . In T. F. Breshanan and R. J Gordon (eds.) The Economics of New Goods, Studies in Income and Wealth. Volume 58. NBER and The University of Chicago press, 375-391.

Baily, M. N. and E Zitzewitz (2001), "Service Sector Productivity Comparisons: Lessons for Measurements”, In C. R. Hulten, E. R. Dean, and M. J. Harper (eds.) New Development in Productivity Analysis. Studies in Income and Wealth. Volume 58. NBER and The University of Chicago press, 419-455.

Baumol, W. J. (1967), "Macroeconomics of Unbalanced growth: The Anatomy of Urban Crises”. American Economic Review 57, 415-26.

Choperena, A. M (1996), “Fast cycle time-driver of innovation and quality”, ResearchTechnology Management, (May-June), 36-40.

Cohen, W. M., and D. A. Levinthal (1990), “Absorptive Capacity. A New Perspective on Learning and Innovation”, Administrative Science Quarterly, No 35, 128-152.

Cohen, W. M. and S. Klepper (1996), “A reprise of size and R\&D”, The Economic Journal 106, 925-951.

Crépon, B., E. Duguet, and J. Mairesse (1998), “Research, Innovation, and Productivity: An Econometric Analysis at the Firm Level”, NBER Working Paper No 6696.

Dean, E. R. and K. Kunze (1992), "Productivity Measurement in Service industries”. In Z. Griliches (ed.) Output Measurement in the service secto, Studies in Income and Wealth, Vol 56. NBER and University of Chicago Press, 73-106.

Deavers, K.L. (1997), “Outsourcing: a corporate competitiveness strategy, not a search for low wages”, Journal of Labor Research 18(4), 503-519.

Estevão, M. and S. Lach (1999), “Measuring temporary labor outsourcing in U.S. manufacturing”, NBER Working paper No 7421 
Falk, M. and B. Koebel (2000), Outsourcing of Services, Imported Materials and the Demand for Heterogeneous Labor: An Application of a Generalized Box-Cox Function. Discussion 00-51, ZEW.

Freeman, C (1991), "Networks of innovators. A synthesis of research issues”, Research Policy, 20, 499-514.

Fuchs, V. R. (1969), “Introduction and Summary”, in V. R Fuchs Productivity in the Service Industries . Conference on Research in Income and Wealth. NBER and Columbia University Press 1-13.

Goux, D. and E Maurin (2000), "Returns to firm-provided training: evidence from French worker-firm matched data”, Labor Economics 7.

Griliches, Z. (1992) “Introduction”, In Z. Griliches (ed.) Output Measurement in the service sector, Studies in Income and Wealth, Vol 56. NBER and University of Chicago Press, 122.

Griliches, Z. and J. Mairesse (1993). “Introduction”, The Journal of Productivity Analysis 4, 5-8.

Griliches, Z (1998), “Returns to R\&D Expenditures in the Private Sector”, Chapter 3, $R \& D$ and Productivity: The Econometric Evidence, Chicago.

Heshmati A. (2003), "Productivity Growth, Efficiency and Outsourcing in Manufacturing and Services", Journal of Economic Surveys 17(1), 79-112.

Janz N., H. Lööf and B.Peters (2004), "Firm Level Innovation and Productivity - Is thedre a Common Story Across Countries?, Problems\& perspectives in management. Forthcoming 2004

Jewkes, J., D. Sawers and R. Stillerman (1958), The sources of invention, New York: St. Martin’s Press.

Klette T. J. and S.Kortum (2002), “Innovating Firms and Aggregate Innovation”, NBER Working Paper No 8819.

Lööf H. and A. Heshmati (2002), "Knowledge Capital and Performance Heterogeneity: An Innovation Study at Firm Level", International Journal of Production Economics 76(1), 61-85. 
Lööf H. and A. Heshmati (2004), "On the Relationship between Innovation and Performance: A Sensitivity Analysis", Economics of Innovation and New Technology, forthcoming.

Mohr, M. F (1992), "Recent and Planned Improvements in the Measurement of Deflation of Services Outputs and Inputs in BEA's Gross Product Originating Estimates”, In Z. Griliches (ed.) Output Measurement in the service sector, NBER and University of Chicago Press, 25-72.

Murray, R. S. Millson, P. Ray, and D. Wilemon (1996), “Strategic partnering for developing new products”, Research-Technology Management, 41-49.

Nordhaus, D. N (1997), "Do Real-Output and real-Wage Measures Capture Reality? The History of Lightning Suggest Not?”, In T.F Bresnahan and R.J Gordon (eds.) The Economics of New Goods, NBER Studies in Income and Wealth, Volume 58, The University of Chicago Press, Chicago.

OECD and Eurostat (1997), "Oslo-Manual, Proposed Guidelines for Collecting and Interpreting Technological Innovation Data”, Organisation for Economic Co-operation and Development, Paris.

Palmberg, C, P. Niininen, H. Toivanen, and T Wahlberg (2000), “ Industrial innovation in Finland, First results of the Sfinno-project”, VTT , Group for technology studies, Working Papers No.47/00

Pyka, A (2000), “Informal networking and industrial life cycles”, Technovation, Vol 20, 2535.

Ravenscraft, D.J. and F.M. Scherer (1982), "The lag structure of returns to research and development, “ Applied Economics 14, 603-620.

Sherwood, M. K (1994), “Difficulties in the measurement of service outputs”, Monthly Labor Review, March 1994.

Triplett, J., and B. Bosworth (1999), Productivity in the Service Sector. Unpublished manuscript.

Ulset, S. (1996), "R\&D outsourcing and central governance: an empirical study of commercial R\&D projects”, Journal of Economic Behavior \& Organization 30(1), 63-82. 


\section{Descriptive Statistics}

Table 1: Major variables.

Means and Standard Deviations. Minimum and Maximum. Weighted values

\begin{tabular}{|c|c|c|c|c|c|c|c|c|}
\hline \multirow[t]{3}{*}{ Panel A } & \multicolumn{8}{|c|}{ Overall samples } \\
\hline & \multicolumn{4}{|c|}{ Manufacturing N=607 } & \multicolumn{4}{|c|}{ Services N=538 } \\
\hline & Mean & $\mathrm{SE}$ & Min & Max & Mean & SE & Min & Max \\
\hline Ordinary Employment & 218 & 781 & 20 & 9,681 & 99 & 238 & 20 & 2,870 \\
\hline Temporary Employment (TE) & 3 & 26 & 0 & 100 & 1 & 5 & 0 & 75 \\
\hline Proportion of firms with TE & .19 & .39 & 0 & 1 & .16 & .37 & 0 & 1 \\
\hline Human capital: Engineers ${ }^{1}$ & .12 & .10 & 0 & .57 & .21 & .25 & 0 & .94 \\
\hline Human capital: Others ${ }^{1}$ & .02 & .03 & 0 & .33 & .12 & .15 & 0 & .69 \\
\hline Sales, 1000 Swedish Crowns ${ }^{2}$ & 1,312 & 764 & 100 & 73,000 & 1,079 & 964 & 113 & 10,000 \\
\hline Value added, 1000 Sw Crowns ${ }^{2}$ & 492 & 437 & 62 & 10,000 & 534 & 372 & 75 & 5355 \\
\hline Physical Capital Investment ${ }^{3}$ & .09 & .09 & 0 & 1.3 & .05 & .05 & 0 & .37 \\
\hline R\&D-investment ${ }^{3}$ & .03 & .06 & 0 & .51 & .06 & .11 & 0 & .76 \\
\hline Innovation output $^{3}$ & .16 & .24 & 0 & 1 & .14 & .25 & 0 & 1 \\
\hline \multirow[t]{3}{*}{ Panel B } & \multicolumn{8}{|c|}{ Innovative samples ${ }^{4}$} \\
\hline & \multicolumn{4}{|c|}{ Manufacturing N=317 } & \multicolumn{4}{|c|}{ Services N=209 } \\
\hline & Mean & $\mathrm{SE}$ & Min & Max & Mean & SE & Min & Max \\
\hline Ordinary Employment & 230 & 756 & 20 & 9,681 & 102 & 269 & 20 & 2,870 \\
\hline Temporary Employment (TE) & 5 & 35 & 0 & 600 & 2 & 6 & 0 & 59 \\
\hline Proportion of firms with $\mathrm{TE}$ & .27 & .44 & 0 & 1 & .25 & 43 & 0 & 1 \\
\hline Human capital: Engineers ${ }^{1}$ & .14 & .11 & 0 & 1 & .22 & .25 & 0 & 1 \\
\hline Human capital: Others ${ }^{1}$ & .02 & .03 & 0 & .20 & .13 & .15 & 0 & .66 \\
\hline Sales, 1000 Swedish Crowns ${ }^{2}$ & 1,453 & 818 & 428 & 7,323 & 1,174 & 1,216 & 183 & 10,000 \\
\hline Value added, 1000 Sw Crowns ${ }^{2}$ & 513 & 229 & 69 & 2,242 & 569 & 508 & 124 & 5,355 \\
\hline Physical Capital Investment ${ }^{3}$ & .09 & .08 & .01 & .60 & .05 & .05 & 0 & .37 \\
\hline R\&D-investment ${ }^{3}$ & .05 & .06 & .01 & .37 & .10 & .16 & .01 & .76 \\
\hline Innovation output $^{3}$ & .29 & .26 & .01 & 1 & .32 & .29 & .01 & 1 \\
\hline
\end{tabular}

Notes:(1) As a proportion of employment. (2) Per employee. (3) As a proportion of sales. (4) A firm is here defined as innovative if is has positive $R \& D$ and positive innovation output 


\section{Descriptive Statistics}

\section{Table 2: Firm Characteristics.}

Means and Standard Deviations. Overall samples.

\begin{tabular}{|c|c|c|c|c|}
\hline \multirow[t]{2}{*}{ Firm characteristics } & \multicolumn{2}{|c|}{$\begin{array}{l}\text { Manufacturing } \\
\mathrm{N}=607\end{array}$} & \multicolumn{2}{|c|}{$\begin{array}{c}\text { Services } \\
\mathrm{N}=538\end{array}$} \\
\hline & Mean & SE & Mean & SE \\
\hline \multicolumn{5}{|l|}{ Product life cycle } \\
\hline Less than 1 year & .02 & .12 & .05 & .21 \\
\hline $1-3$ years & .10 & .30 & .19 & .39 \\
\hline 4-6 years & .23 & .42 & .28 & .45 \\
\hline 7-9 years & .17 & .38 & .10 & .30 \\
\hline More than 9 years & .48 & 50 & .38 & .46 \\
\hline \multicolumn{5}{|l|}{ Growth rate ( $t / t-2)$ on the firm's main market } \\
\hline Strong & .30 & .46 & .42 & .49 \\
\hline Weak & .43 & .50 & .38 & .49 \\
\hline No growth rate & .22 & .41 & .17 & .37 \\
\hline Negative growth rate & .05 & .41 & .04 & .19 \\
\hline \multicolumn{5}{|l|}{ The firms' main customer } \\
\hline Foreign customer & .29 & .46 & .08 & .28 \\
\hline Domestic: Manufacturing firm & .35 & .48 & .27 & .45 \\
\hline Domestic: Service firm & .05 & .22 & .25 & .43 \\
\hline Domestic: Other firm & .11 & .31 & .09 & .28 \\
\hline Domestic: Public sector & .04 & .20 & .10 & .30 \\
\hline Domestic: Household & .03 & .17 & .05 & .22 \\
\hline Domestic: Non profit organizations & .01 & .09 & .04 & .20 \\
\hline \multicolumn{5}{|l|}{$\begin{array}{l}\text { Critical importance for competitiveness } \\
\text { of the firm's products }\end{array}$} \\
\hline Quality & .68 & .47 & .68 & .46 \\
\hline Content of knowledge & .29 & .45 & .50 & .50 \\
\hline Price & .31 & .44 & .20 & .40 \\
\hline Brand-name +Uniqueness +Design & .30 & .46 & .27 & .44 \\
\hline \multicolumn{5}{|l|}{ Innovation activities } \\
\hline Product (good or service) innovation & .69 & .46 & .64 & .48 \\
\hline Process innovation & .41 & .49 & .39 & .49 \\
\hline Organizational innovations & .52 & .55 & 55 & .50 \\
\hline Cooperation on innovation (with external partner) & .48 & .50 & .36 & .48 \\
\hline Purchase of professional service for innovation & .44 & .50 & .33 & .47 \\
\hline $\begin{array}{l}\text { "Innovative firms" defined as firms with positive } \\
\text { innovation input and positive innovation output }\end{array}$ & .53 & .49 & .40 & .49 \\
\hline
\end{tabular}




\section{Descriptive Statistics}

Table 3: Firm Characteristics.

Means and Standard Deviations. Innovation samples.

\begin{tabular}{|c|c|c|c|c|}
\hline \multirow[t]{2}{*}{ Firm characteristics } & \multicolumn{2}{|c|}{$\begin{array}{l}\text { Manufacturing } \\
\mathrm{N}=317\end{array}$} & \multicolumn{2}{|c|}{$\begin{array}{c}\text { Services } \\
\mathrm{N}=209\end{array}$} \\
\hline & Mean & SE & Mean & SE \\
\hline \multicolumn{5}{|l|}{ Strategy of innovation, critical importance } \\
\hline Improving quality on existing products & .44 & .47 & .67 & .47 \\
\hline Opening up new markets/increase market share & .61 & .49 & .64 & .48 \\
\hline Extending product range & .41 & .49 & .49 & .50 \\
\hline Reducing products being phased out & .49 & .50 & 29 & 46 \\
\hline \multicolumn{5}{|l|}{ Very important sources of information for innovation } \\
\hline Within the firm or within the group & .80 & .40 & .74 & .43 \\
\hline Market (Customers, competitors, suppliers) & .77 & .42 & .75 & .43 \\
\hline $\begin{array}{l}\text { Other (Consultancies, universities, inventors, non-profit research } \\
\text { institutes, patent disclosures, scientific literature or meetings, ICT } \\
\text { and exhibitions) }\end{array}$ & .29 & .46 & .36 & .48 \\
\hline \multicolumn{5}{|l|}{ Cooperation on Innovation } \\
\hline Within the group & .28 & .45 & .32 & .47 \\
\hline Market (Customers, competitors, suppliers). & .61 & .49 & .63 & .48 \\
\hline $\begin{array}{l}\text { Other (Consultancies, universities, investors and non-profit research } \\
\text { institutes, patent). }\end{array}$ & .24 & .43 & .27 & .44 \\
\hline \multicolumn{5}{|l|}{$\begin{array}{l}\text { Geographic localization of innovation partners (Here the group, or } \\
\text { customers, competitors or suppliers.) }\end{array}$} \\
\hline Regional & .28 & .45 & .43 & .50 \\
\hline National & .46 & .50 & .52 & .50 \\
\hline Global & .57 & .50 & .33 & .48 \\
\hline \multicolumn{5}{|l|}{ Obstacles to innovation } \\
\hline Competence and knowledge problems & .31 & .46 & .22 & .42 \\
\hline Economic and financial problems & .26 & .44 & .22 & .42 \\
\hline Organizational problem & .25 & .44 & .19 & .39 \\
\hline Market problem & .11 & .31 & .13 & .33 \\
\hline
\end{tabular}

Note: A firm is here defined as innovative if is has positive R\&D and positive innovation output 


\section{Correlation Analysis}

\section{Table 4:}

Panel A

Innovative knowledge intensive manufacturing firms. Number of observations: 317. Logarithmic values.

\begin{tabular}{|l|lllllll|}
\hline & $\begin{array}{l}\text { Labor } \\
\text { produc- } \\
\text { tivity }\end{array}$ & $\begin{array}{l}\text { Innovatio } \\
\text { n output }\end{array}$ & $\begin{array}{l}\text { Innovatio } \\
\text { n input }\end{array}$ & $\begin{array}{l}\text { Human } \\
\text { capital } \\
\text { Engineers }\end{array}$ & $\begin{array}{l}\text { Human } \\
\text { capital } \\
\text { Other }\end{array}$ & $\begin{array}{l}\text { Physical } \\
\text { capital }\end{array}$ & $\begin{array}{l}\text { Size } \\
\text { Emp- } \\
\text { loyees }\end{array}$ \\
\hline Lab Product. & 1 & & & & & \\
Inn Output & $.18^{* * *}$ & 1 & & & & \\
Inn Input & $.17^{* * *}$ & $.26^{* * *}$ & 1 & & & \\
Hum Cap E & $.33^{* * *}$ & $.21^{* * *}$ & $.27^{* * *}$ & 1 & & \\
Hum Cap O & $.29^{* * *}$ & .08 & $.31^{* * *}$ & $.27^{* * *}$ & 1 & \\
Phys Cap & .06 & -.08 & .11 & -.09 & .12 & 1 & $.34^{* * *}$ \\
Size & .18 & .02 & .01 & $.25^{* * *}$ & $.16^{* * *}$ & 1.000 \\
\hline
\end{tabular}

Note: Significant at the $1 \%$ level of significance (***)

\section{Panel B}

Innovative knowledge intensive service firms. Number of observations: 209

Logarithmic values.

\begin{tabular}{|l|lllllll|}
\hline & $\begin{array}{l}\text { Labor } \\
\text { produc- } \\
\text { tivity }\end{array}$ & $\begin{array}{l}\text { Innovatio } \\
\text { n output }\end{array}$ & $\begin{array}{l}\text { Innovatio } \\
\mathrm{n} \text { input }\end{array}$ & $\begin{array}{l}\text { Human } \\
\text { capital } \\
\text { Engineers }\end{array}$ & $\begin{array}{l}\text { Human } \\
\text { capital } \\
\text { Other }\end{array}$ & $\begin{array}{l}\text { Physical } \\
\text { capital }\end{array}$ & $\begin{array}{l}\text { Size } \\
\text { Emp. }\end{array}$ \\
\hline Lab product. & 1 & & & & & & \\
Inn Output & $.42^{* * *}$ & 1 & & & & & \\
Inn Input & $.18^{* * *}$ & $.44^{* * *}$ & 1 & & & & \\
Hum Cap E & $.21^{* * *}$ & .13 & .10 & 1 & & & \\
Hum Cap O & .11 & $.20^{* * *}$ & .15 & $-.38^{* * *}$ & 1 & & \\
Phys Cap & .14 & .14 & .10 & .06 & .01 & 1 & \\
Size & -.11 & -.16 & -.13 & -.02 & .02 & -.04 & 1 \\
\hline
\end{tabular}

Note: Significant at the $1 \%$ level of significance (***) 


\section{Summary regressions}

Table 5: The whole model. Selected variables.

\section{Panel A:}

Step 1 of the model; Generalized tobit.

Overall sample of knowledge intensive manufacturing and business services. Number of observations: 1,145 .

\begin{tabular}{|c|c|c|}
\hline & Coeff & SE \\
\hline \multicolumn{3}{|l|}{ Equation 1: Selectivity equation } \\
\hline \multicolumn{3}{|l|}{ Dependent variable: Probability of R\&D-investments } \\
\hline Log firm size; employment & 0.041 & 0.035 \\
\hline \multicolumn{3}{|l|}{ Equation 2: Research investment equation } \\
\hline \multicolumn{3}{|l|}{ Dependent variable: Log innovation expenditures per employee } \\
\hline LR test of independent equations & $25.56(0$. & \\
\hline
\end{tabular}

\section{Panel B:}

Step 2 of the model; Instrument variable method. 3SLS.

Innovative sample of knowledge intensive manufacturing and business services. Number of observations: 526 .

\begin{tabular}{|lll|}
\hline & Coeff & SE \\
\hline Equation 3: Innovation output equation & & \\
Dependent variable: Log innovation sales per employee & $0.434^{* * *}$ & 0.122 \\
Inverse Mills' ratio & $0.870^{* * *}$ & 0.200 \\
& & \\
Equation 4: Productivity equation & & \\
Dependent variable: Log innovation expenditures per employee & & \\
Log innovation sales per employee & $0.162^{* * *}$ & 0.033 \\
Human capital: engineers/total employment & $0.473^{* * *}$ & 0.093 \\
Human capital: others with a university degree/total employment & $0.738^{* * *}$ & 0.157 \\
Log gross investment per employee & $0.036^{* *}$ & 0.015 \\
& & \\
R-square equation 3 & 0.27 & \\
Root MSE equation 3 & 1.07 & \\
R-square equation 4 & 0.17 & \\
Root MSE equation 4 & 0.37 & \\
\hline
\end{tabular}

Notes: Industry dummies and intercept are included in each regression. Significant at the $1 \%(* * *)$, $5 \%(* *)$ and $10 \%(*)$ levels of significance 


\section{Regression Results}

Table 6: Selection equation.

Dependent variable: Probability of doing innovation.

\begin{tabular}{|c|c|c|c|c|}
\hline & \multicolumn{2}{|c|}{$\begin{array}{c}\text { Manufacturing } \\
\qquad \mathrm{N}=607\end{array}$} & \multicolumn{2}{|c|}{$\begin{array}{c}\text { Services } \\
\mathrm{N}=538\end{array}$} \\
\hline & Coeff & $\mathrm{SE}$ & Coeff & $\mathrm{SE}$ \\
\hline Firm Size: Ordinary employment ${ }^{1}$ & $0.074^{*}$ & 0.044 & -0.002 & 0.058 \\
\hline Temporary employment ${ }^{2}$ & $0.520^{* * *}$ & 0.129 & $0.490^{* * *}$ & 0.139 \\
\hline Gross investment $^{1}$ & $0.142^{* * *}$ & 0.046 & 0.041 & 0.041 \\
\hline The main customers are located abroad ${ }^{2}$ & $0.520^{* * *}$ & 0.104 & 0.177 & 0.168 \\
\hline \multicolumn{5}{|c|}{ Very important factors for the competitiveness of the producs ${ }^{2}$} \\
\hline Price & 0.120 & 0.117 & 0.182 & 0.151 \\
\hline Quality & $0.695^{* * *}$ & 0.127 & 0.797 & 0.155 \\
\hline Knowledge content & 0.194 & 0.128 & $0.440^{* * *}$ & 0.136 \\
\hline Brand-name, design, uniqueness & $0.575^{* * *}$ & 0.128 & $0.241^{*}$ & 0.135 \\
\hline \multicolumn{5}{|l|}{ Product life cycle $e^{2}$} \\
\hline 3 years or less & -0.272 & 0.666 & 0.050 & 0.171 \\
\hline 4-7 years & -0.113 & 0.142 & 0.149 & 0.171 \\
\hline 7-9 years: Reference & - & - & - & - \\
\hline More than 9 years & $-0.342^{* *}$ & 0.137 & -0.242 & 0.135 \\
\hline LR test ${ }^{\mathrm{a}}$ & 36.67 & 0.000 & 9.06 & 0.002 \\
\hline
\end{tabular}

Notes: Industry dummies and intercept are included in each regression. Significant at the $1 \%(* * *)$, $5 \%(* *)$ and 10\% (*) levels of significance. (1) Log variables. (2) Dummy variables. (a) LR test of independence of the selection equation (equation 2 reported in Table 6) and innovation input equation (reported in Table 7). 


\section{Regression Results}

\section{Table 7: Innovation Input Equation.}

Dependent variable: Logarithm of innovation expenditure per employee.

\begin{tabular}{|c|c|c|c|c|}
\hline & \multicolumn{2}{|c|}{ Manufacturing N=317 } & \multicolumn{2}{|c|}{ Services $N=209$} \\
\hline & Coeff & SE & Coeff & SE \\
\hline Firm Size: Ordinary empoyment ${ }^{1}$ & $-0.148^{* *}$ & 0.078 & $-0.408^{* * *}$ & 0.122 \\
\hline Temporary employment $^{1}$ & $0.169^{* *}$ & 0.072 & -0.051 & 0.136 \\
\hline \multicolumn{5}{|l|}{ Obstacles to Innovation $^{2}$} \\
\hline Cost/Financing issues & $0.309^{*}$ & 0.158 & -0.025 & 0.265 \\
\hline Demand/Market issues & -0.138 & 0.220 & 0.161 & 0.307 \\
\hline Organizational issues & 0.083 & 0.164 & 0.415 & 0.282 \\
\hline Lack of Skill/Knowledge & 0.221 & 0.151 & 0.178 & 0.266 \\
\hline \multicolumn{5}{|c|}{ Localization of partners on innovation ${ }^{2}$} \\
\hline Regional collaboration & -0.023 & 0.162 & -0.146 & 0.223 \\
\hline National collaboration & $-0.289^{*}$ & 0.158 & -0.175 & 0.229 \\
\hline Global collaboration & $0.422^{* * *}$ & 0.152 & $0.924^{* * *}$ & 0.226 \\
\hline \multicolumn{5}{|c|}{ Very important sources of information for innovation ${ }^{2}$} \\
\hline Within the firm or the group & -0.084 & 0.165 & 0.277 & 0.298 \\
\hline Customers, suppliers, competitors & $0.478^{* * *}$ & 0.150 & 0.332 & 0.221 \\
\hline Universities, consultancies etc. & -0.181 & 0.165 & 0.065 & 0.207 \\
\hline \multicolumn{5}{|c|}{ Very important factors for the competitiveness of the products ${ }^{2}$} \\
\hline Price & -0.178 & 0.172 & $-0.616^{* *}$ & 0.296 \\
\hline Quality & $-0.553^{* * *}$ & 0.210 & $-1.148^{* * *}$ & 0.365 \\
\hline Content of knowledge & 0.296 & 0.181 & -0.309 & 0.272 \\
\hline Brand name, uniqueness, design & $-0.343^{*}$ & 0.179 & 0.051 & 0.254 \\
\hline
\end{tabular}

Notes: Industry dummies and intercept are included in each regression. Significant at the $1 \%\left({ }^{* * *}\right), 5 \%\left({ }^{* *}\right)$ and 10\% (*) levels of significance. (1)Log variables. (2) Dummy variables. 


\section{Regression Results}

Table 8: Innovation output equation.

Dependent variable: Logarithm of innovation sales per employee.

\begin{tabular}{|c|c|c|c|c|c|c|c|c|}
\hline & \multicolumn{4}{|c|}{ Manufacturing N=317 } & \multicolumn{4}{|c|}{ Services N=209 } \\
\hline & \multicolumn{2}{|c|}{ 3SLS } & \multicolumn{2}{|c|}{ 2SLS } & \multicolumn{2}{|c|}{ 3SLS } & \multicolumn{2}{|c|}{ 2SLS } \\
\hline & Coef. & SE & Coef. & SE & Coef. & SE & Coef. & SE \\
\hline Innov. Input ${ }^{1}$ & $0.451^{* * *}$ & 0.141 & $0.506^{* * *}$ & 0.147 & $0.432^{* *}$ & 0.198 & $0.571^{*}$ & 0.290 \\
\hline Labor Prod ${ }^{1}$ & $1.101^{* *}$ & 0.480 & $1.145^{* *}$ & 0.495 & $1.252^{*}$ & 0.693 & 1.318 & 0.841 \\
\hline Mills Ratio ${ }^{1}$ & $-0.793^{* * *}$ & 0.237 & $-0.649^{* * *}$ & 0.275 & $-1.226^{* * *}$ & 0.397 & $-1.116^{* * *}$ & 0.537 \\
\hline Gross invest $^{1}$ & $-0.190^{* * *}$ & 0.074 & $-0.168^{*}$ & 0.087 & -0.043 & 0.067 & -0.011 & 0.076 \\
\hline Firm size $^{1}$ & -0.030 & 0.128 & -0.014 & 0.059 & -0.005 & 0.128 & 0.058 & 0.157 \\
\hline \multicolumn{9}{|c|}{ Innovation strategy ${ }^{2}$} \\
\hline Replace prod & $0.253^{* *}$ & 0.105 & $0.275^{* *}$ & 0.137 & $0.381^{* *}$ & 0.167 & 0.230 & 0.204 \\
\hline Improve qual & -0.009 & 0.103 & 0.047 & 0.140 & 0.201 & 0.222 & $0.551^{*}$ & 0.281 \\
\hline Extend range & $-0.294^{* * *}$ & 0.108 & -0.219 & 0.137 & -0.092 & 0.146 & -0.145 & 0.189 \\
\hline Open up mark & 0.069 & 0.106 & 0.181 & 0.145 & 0.011 & 0.149 & 0.012 & 0.213 \\
\hline \multicolumn{9}{|c|}{ Very important sources of information. for innovation ${ }^{2}$} \\
\hline Firm/Group & 0.196 & 0.108 & $0.308^{*}$ & 0.162 & $-0.429^{* *}$ & 0.172 & $-0.591^{* * *}$ & 0.220 \\
\hline Market & $-0.479^{* * *}$ & 0.143 & $-0.495^{* * *}$ & 0.182 & 0.073 & 0.167 & 0.1473 & 0.233 \\
\hline Other & -0.019 & 0.112 & 0.102 & 0.153 & 0.145 & 0.185 & -0.030 & 0.229 \\
\hline \multicolumn{9}{|c|}{ Very important cooperation partners on innovation ${ }^{2}$} \\
\hline The group & $-0.289^{* * *}$ & 0.129 & $-0.277^{* *}$ & 0.138 & 0.223 & 0.185 & 0.245 & 0.238 \\
\hline Market $^{3}$ & -0.047 & 0.121 & -0.083 & 0.131 & 0.076 & 0.167 & 0.086 & 0.205 \\
\hline Other & $-0.402^{* * *}$ & 0.137 & $-0.414^{* *}$ & 0.154 & -0.126 & 0.181 & -0.059 & 0.206 \\
\hline \multicolumn{9}{|c|}{ Localization of partners on innovation ${ }^{2}$} \\
\hline Regional & -0.186 & 0.121 & -0.217 & 0.153 & 0.167 & 0.161 & 0.173 & 0.228 \\
\hline National & $0.332^{* * *}$ & 0.120 & $0.398^{* * *}$ & 0.159 & -0.123 & 0.185 & -0.049 & 0.239 \\
\hline Global & $-0.306^{* *}$ & 0.120 & $-0.386^{* * *}$ & 0.172 & -0.416 & 0.268 & -0.657 & 0.376 \\
\hline \multicolumn{9}{|c|}{ Product life cycle ${ }^{2}$} \\
\hline$<=3$ years & $0.658^{* * *}$ & 0.209 & $0.660^{* * *}$ & 0.211 & 0.196 & 0.289 & 0.048 & 0.368 \\
\hline 4-7 years & 0.078 & 0.142 & 0.144 & 0.169 & 0.078 & 0.243 & -0.250 & 0.287 \\
\hline 7-9 years ${ }^{a}$ & - & - & - & - & - & - & - & - \\
\hline$>9$ years & 0.023 & 0.138 & -0.002 & 0.171 & 0.158 & 0.423 & -0.326 & 0.327 \\
\hline \multicolumn{9}{|c|}{ Growth rate on the firms' main market ${ }^{2}$} \\
\hline High & 0.069 & 0.123 & -0.084 & 0.158 & $0.275^{*}$ & 0.160 & 0.360 & 0.228 \\
\hline Low & - & - & - & - & - & - & - & - \\
\hline No growth & $-0.263^{* *}$ & 0.131 & -0.157 & 0.186 & 0.059 & 0.230 & 0.265 & 0.278 \\
\hline R-Square & & & & & & & & \\
\hline Root MSE & & & & & & & & \\
\hline
\end{tabular}

Notes: Industry dummies and intercept are included in each regression. Significant at the $1 \%(* * *), 5 \%(* *)$ and $10 \%(*)$ levels of significance. Significant at the 1\% (***), 5\% (**) and 10\% (*) levels of significance. (1) Log variable. Intensity terms; per employee. (2) Dummy variable (3) Market: Customers, suppliers and competitors. Consultancies, universities, inventors, non-profit research institutes, patent disclosures, scientific literature or meetings, ICT and exhibitions (4) Other: Universities, consultancies, non-profit research institutes, inventors. (a) Reference. 


\section{Regression Results}

\section{Table 9: Productivity equation.}

Dependent variable: Logarithm of value added per employee.

\begin{tabular}{|c|c|c|c|c|c|c|c|c|}
\hline & \multicolumn{4}{|c|}{ Manufacturing N=317 } & \multicolumn{4}{|c|}{ Services N=209 } \\
\hline & \multicolumn{2}{|c|}{ 3SLS } & \multicolumn{2}{|c|}{ 2SLS } & \multicolumn{2}{|c|}{ 3SLS } & \multicolumn{2}{|c|}{ 2SLS } \\
\hline & Coef. & SE & Coef. & SE & Coef. & SE & Coef. & SE \\
\hline Innov. Output ${ }^{1}$ & $0.110^{* * *}$ & 0.038 & $0.116^{* * *}$ & 0.037 & $0.141^{* * *}$ & 0.048 & $0.150^{* * *}$ & 0.053 \\
\hline Hum Cap Eng ${ }^{1}$ & $0.793^{* * *}$ & 0.190 & $0.704^{* * *}$ & 0.239 & $0.297^{*}$ & 0.157 & $0.327^{* *}$ & 0.138 \\
\hline Hum Cap Oth ${ }^{1}$ & $3.115^{* * *}$ & 0.692 & $3.321^{* * *}$ & 1.034 & $0.584^{* * *}$ & 0.217 & $0.440^{* *}$ & 0.222 \\
\hline Gross invest & 0.028 & 0.022 & 0.032 & 0.029 & $0.049^{* *}$ & 0.023 & 0.050 & 0.036 \\
\hline Firm Size $^{1}$ & 0.015 & 0.017 & 0.020 & 0.015 & -0.011 & 0.037 & -0.003 & 0.027 \\
\hline Process Innov $^{2}$ & 0.026 & 0.034 & -0.029 & 0.040 & -0.079 & 0.059 & $-0.170^{* *}$ & 0.072 \\
\hline Org. Innov ${ }^{2}$ & -0.001 & 0.033 & -0.024 & 0.041 & $-0.120^{* *}$ & 0.064 & -0.101 & 0.099 \\
\hline \multicolumn{9}{|c|}{ Very important cooperation partners on innovation ${ }^{2}$} \\
\hline The group & 0.056 & 0.040 & 0.051 & 0.044 & 0.073 & 0.064 & 0.092 & 0.104 \\
\hline Market $^{3}$ & 0.015 & 0.036 & 0.015 & 0.038 & -0.037 & 0.061 & -0.049 & 0.073 \\
\hline Universities etc ${ }^{4}$ & $0.077^{*}$ & 0.046 & $0.084^{*}$ & 0.050 & 0.019 & 0.065 & 0.019 & 0.072 \\
\hline R-Square & \multicolumn{2}{|c|}{0.21} & \multicolumn{2}{|c|}{0.21} & \multicolumn{2}{|c|}{0.27} & \multicolumn{2}{|c|}{0.28} \\
\hline Root MSE & \multicolumn{2}{|c|}{31} & \multicolumn{2}{|c|}{0.32} & \multicolumn{2}{|c|}{0.39} & \multicolumn{2}{|c|}{0.42} \\
\hline
\end{tabular}

Notes: Industry dummies and intercept are included in each regression. Significant at the 1\% (***), 5\% (**) and 10\% (*) levels of significance. (1) Log variable. Intensity terms; per employee. (2) Dummy variable (3) Market: Customers, suppliers and competitors. (4) Other: Universities, consultancies, non profit research institutes, inventors. 


\section{Appendix A}

\section{Treatment of missing values and outliers}

Panel A

Register data. Number of observations 1,145

\begin{tabular}{|lcccc|}
\hline Variable & Missing values & Treatment & Outliers & Treatment \\
\hline Sales & 0 & - & 3 & Censoring \\
Value added & 0 & & 1 & Censoring \\
Employment & 0 & - & 0 & - \\
Gross investment & 2 & $\mathrm{MV}=0$ & 13 & Censoring \\
Human capital & 0 & - & 0 & - \\
\hline
\end{tabular}

Panel B

Survey data. Number of observations 1,145

\begin{tabular}{|lcccc|}
\hline Variable & Missing values & Treatment & Outliers & Treatment \\
\hline Temporary employment & 0 & - & 0 & - \\
Export & 646 & $\mathrm{MV}=0$ & 0 & - \\
R\&D & 174 & $\mathrm{MV}=0$ & 3 & Censoring \\
Innovation output & 172 & $\mathrm{MV}=0$ & 0 & - \\
Other & Variation & Imputation & - & - \\
\hline
\end{tabular}

Notes: The observations on export contain an unsatisfactory amount of missing values. One alternative here should be to impute values, however the method used is to replace the missing values with a zero value. The missing values on R\&D and innovation are assumed to be zero. The numbers of outliers are fairly low and an sensitivity analysis shows that the influence of outliers is neglectable.

\section{Productivity performance, knowledge intensive manufacturing and services}

Level and growth of productivity att industry level. Swedish Crowns and percent

\begin{tabular}{|c|c|c|c|c|c|}
\hline \multirow[t]{2}{*}{ Industry } & \multicolumn{2}{|c|}{$\begin{array}{l}\text { Value added per working } \\
\text { hour in the year } 1991 \text { prices. }\end{array}$} & \multicolumn{3}{|c|}{$\begin{array}{l}\text { Annual growth rate 1980-1998. } \\
\text { Percent }\end{array}$} \\
\hline & 1980 & 1998 & $\begin{array}{c}\text { Labor } \\
\text { productivity }\end{array}$ & Value added & Hours \\
\hline $\begin{array}{l}\text { Knowledge-intensive } \\
\text { manufacturing }\end{array}$ & 142 & 325 & 4.7 & 4.5 & -0.2 \\
\hline $\begin{array}{l}\text { Electrical and communication } \\
\text { equipment }\end{array}$ & 84 & 577 & 11.3 & 10.8 & -0.4 \\
\hline $\begin{array}{l}\text { Pharmaceuticals, soap, per } \\
\text { fumes }\end{array}$ & 301 & 641 & 4.3 & 4.5 & 2.3 \\
\hline Instruments & 190 & 331 & 3.1 & 5.7 & 2.5 \\
\hline Transport equipment & 164 & 283 & 3.1 & 2.6 & -0.4 \\
\hline Machinery \& equipment. & 136 & 197 & 2 & 1.6 & -0.5 \\
\hline Office machinery \& computers & 158 & 142 & -0.6 & -3.3 & -2.6 \\
\hline Business services & 189 & 227 & 1.0 & 4.8 & 3.8 \\
\hline
\end{tabular}

Notes: The official statistics report that annual labor productivity has increased with about 5 percent for the aggregate of knowledge intensive manufacturing studied in this paper during the two recent decades. This is in sharp contrast to the reported 1 percent in labor productivity for business services. One possible explanation for this large difference in growth rates is that that is much harder to increase productivity in service producing industries than in manufacturing. But the figures might also be non correct. It is well documented in the literature that there are notorious problem measuring service production. Source: Statistics Sweden. 